\title{
REKONSTRUKSI SURAT KUASA MEMASANG HIPOTEK DENGAN PENCANTUMAN KLAUSULA KEWAJIBAN PENGIKATAN SISTER SHIP MANAKALA JALUR PELAYARAN DOMINAN LINTAS BATAS NEGARA
}

\author{
Fani Martiawan Kumara Putra \\ Fakultas Hukum Universitas Wijaya Kusuma Surabaya \\ e-mail: fanimartiawan@gmail.com
}

\begin{abstract}
ABSTRAK
Jaminan Hipotek saat ini dapat dikatakan sebagai lembaga jaminan yang paling dibutuhkan dan diminati oleh masyarakat yang merupakan pelaku usaha di bidang transportasi laut. Kendati demikian aturan mengenai Hipotek ini keberadaannya tersebar dalam beberapa peraturan perundang-undangan. Saat ini Hipotek diatur dalam Undang-Undang Nomor 17 Tahun 2008 Tentang Pelayaran, dan Peraturan Menteri Perhubungan Nomor 39 Tahun 2017 Tentang Pendaftaran dan Kebangsaan Kapal. Mengenai perlindungan hukum bagi pihak kreditor dan debitor, salah satunya adalah dihadirkan lembaga eksekusi manakala pihak debitor sudah dinilai wanprestasi. Pada penelitian dan penulisan yang dilakukan penulis sebelumnya, telah dibahas dan ditemukan bahwa guna mengakomodir kebutuhan aturan hukum akibat tidak diratifikasinya konvensi Arrest of Ships 1999, adalah dengan mencantumkan klausula Sister Ship dalam salah satu dokumen penjaminan Hipotek kapal, dokumen yang yang tepat dalam hal ini adalah SKMH. Kendati demikian walaupun hal ini dipraktekkan, tetap ada hambatannya karena SKMH bukanlah merupakan kewajiban. Hasil yang didapatkan dari penulisan ini adalah perlu adanya campur tangan pemerintah untuk memfasilitasi, baik itu berupa Undang-Undang, Peraturan Pemerintah, ataupun Peraturan Menteri Perhubungan. Isinya adalah kewajiban untuk menggunakan klausula sister ship manakala kapal debitor yang akan dijaminkan itu berlayar melintasi yurisdiksi Indonesia.
\end{abstract}

Kata Kunci: Hipotek; Eksekusi; Sister Ship

\section{ABSTRACT}

The current mortgage guarantee can be said as the most needed and sought-after guarantee institution by the people who are business actors in the field of sea transportation. However, the rules regarding mortgages are spread in several laws and regulations. Currently Mortgages are regulated in Law Number 17 of 2008 concerning Shipping, and Minister of Transportation Regulation Number 39 of 2017 concerning Registration and Nationality of Ships. Regarding legal protection for creditors and debtors, one of them is the execution institution when the debtor has been judged as default. In the previous research and writing by the author, it was discussed and found that in order to accommodate the needs of the rule of law due to the ratification of the 1999 Arrest of Ships convention, is to include the Sister Ship clause in one of the ship's mortgage guarantee documents, the right document in this case SKMH. Nevertheless, even though this is practiced, there are still obstacles because SKMH is not an obligation. The results obtained from this writing are that there is a need for government intervention to facilitate, whether in the form of Laws, Government Regulations, or Minister of Transportation Regulations. Its contents are the obligation to use the sister ship clause when the debtor ship to be pledged sailing across the Indonesian jurisdiction.

Keywords: Mortgage; Execution; Sister Ship 


\section{PENDAHULUAN}

Kehadiran lembaga perkreditan memiliki peran sangat penting dalam kegiatan dan pertumbuhan perekonomian serta pembangunan di era seperti saat ini. Lembaga pembiayaan pada saat ini lebih sering digunakan untuk benda bergerak terdaftar seperti mobil dan motor, sedangkan untuk perkembangan usaha, lebih sering digunakan lembaga perkreditan. Lembaga perkreditan dapat berupa Bank atau pun Non-Bank, namun pada saat ini, lembaga perkreditan yang sering digunakan adalah Bank. Untuk menjaga kesehatan dari kegiatan perkreditan tersebut, maka sudah semestinya usaha perkreditan diiringi pula dengan penjaminan, hal ini bertujuan untuk memberi keamanan dan kepastian hukum dalam pemberian kredit, baik itu untuk pihak yang berutang ataupun pihak yang berpiutang.

Penjaminan ini merupakan salah satu bentuk dari prinsip kehati-hatian yang harus diterapkan oleh Bank sebagai lembaga perkreditan, diatur dalam UndangUndang No. 7 Tahun 1992 tentang Perbankan, sebagaimana telah dirubah dengan Undang-Undang No. 10 Tahun 1998 Tentang Perbankan (selanjutnya disebut UU Perbankan) Pasal 2-nya menegaskan bahwa Perbankan Indonesia dalam melakukan usahanya berasaskan demokrasi ekonomi dengan menggunakan prinsip kehati-hatian. Prinsip kehatihatian itu diatur lebih lanjut dalam Pasal 29 ayat (2) UU Perbankan yang mengatur bahwa Bank wajib memelihara tingkat kesehatan Bank sesuai dengan kecukupan modal, kualitas aset, kualitas manajemen, likuiditas, dan rentabilitas, solvabilitas, dan aspek lain yang berhubungan dengan usaha Bank, dan wajib melakukan kegiatan usaha dengan prinsip kehati-hatian ini. Prinsip kehati-hatian Bank ini pada prakteknya diwujudkan dalam bentuk 6C, yaitu Character, Capacity, Capital, Collateral, Condition of Economy, dan Constraint.

Berkaitan dengan hal perkreditan sebagaimana di atas, maka yang perlu diperhatikan adalah aspek collateral yang artinya adalah penjaminan. Sesuai dengan namanya, yaitu jaminan, maka perlu adanya suatu benda atau objek yang akan dijaminkan untuk meyakinkan dan memperoleh dana dari pemberi pinjaman. Disamping itu perlu juga diperhatikan mengenai lembaga jaminannya, mengingat nantinya ketentuan prosedural akan lembaga jaminan ini yang akan menentukan sah atau tidaknya proses penjaminannya. Terdapat 4 (empat) lembaga jaminan yang diakui di Indonesia, salah satunya dan yang akan dibahas dalam penelitian ini adalah Hipotek.

Hipotek merupakan bentuk dukungan pemerintah untuk kegiatan bisnis yang turut membuat perekonomian di Indonesia berkembang, yaitu bidang transportasi laut, perkapalan atau pelayaran. Usaha perkapalan sendiri di Indonesia merupakan usaha yang cukup menjanjikan karena mengingat wilayah Indonesia sebagian besar terdiri dari lautan, hal ini dikarenakan Indonesia memiliki dua pertiga wilayah laut dibandingkan dengan seluruh daratan pulau yang berada di Indonesia. Tidak luput dari tuntutan perkembangan perusahaan, para pelaku bisnis pelayaran atau perkapalan pun membutuhkan modal cukup besar untuk meningkatkan kualitas usahanya, yang dapat difasilitasi dengan kegiatan perkreditan dengan obyek jaminan armada pelayarannya, yaitu kapal. Sebagai lembaga jaminannya, dapat digunakan lembaga jaminan Hipotek (manakala kapal tersebut terdaftar) atau menggunakan lembaga jaminan Fidusia (manakala kapal tersebut tidak terdaftar di Indonesia).

Jaminan Hipotek saat ini dapat dikatakan sebagai lembaga jaminan yang paling dibutuhkan dan diminati oleh masyarakat yang merupakan pelaku usaha di bidang transportasi laut. Kendati demikian aturan mengenai Hipotek ini keberadaannya tersebar dalam beberapa peraturan perundang-undangan. Saat ini Hipotek diatur dalam Undang-Undang No. 17 Tahun 2008 tentang Pelayaran (selanjutnya disebut UU Pelayaran), dan Peraturan Menteri Perhubungan Nomor 39 Tahun 2017 tentang Pendaftaran dan Kebangsaan Kapal (selanjutnya disebut PERMENHUB Pendaftaran Kapal). Mengenai perlindungan hukum bagi pihak kreditor dan debitor, salah satunya adalah dihadirkan lembaga eksekusi manakala pihak debitor sudah dinilai wanprestasi.

Sesuai Pasal 224 HIR jo. Pasal 60 ayat (4) UU Pelayaran jis. Pasal 31 ayat (3) PERMENHUB Pendaftaran Kapal, diberikan kepada pihak kreditor berupa hak eksekusi kapal yang dibebani Hipoteknya. Pertama dengan cara memanfaatkan titel eksekutorial yang terdapat dalam grosse akta Hipotek kapal. Selain itu yang kedua adalah melalui Pasal 1178 ayat (2) BW, yang mana diberikan hak kepada pemegang Hipotek kapal (kreditor) untuk melaksanakan 
eksekusi melalui lembaga Parate Executie dengan mencantumkan klausula Eigenmachtige Verkoop (yang pada prakteknya dicantumkan dalam Surat Kuasa Memasang Hipotek (selanjutnya disebut SKMH)). Eksekusi Hipotek kapal hanya dapat dilakukan dengan kedua cara ini.

Eksekusi objek jaminan Hipotek kapal sebagai bentuk perlindungan kreditor dalam penyelesaian kredit, menemui permasalahan dan tidak dapat dilaksanakan manakala objek kapal tersebut sedang berada di luar yurisdiksi Indonesia. Keadaan ini disebabkan adanya kekosongan hukum di Indonesia untuk meletakkan sita eksekusi dan melakukan eksekusi atas kapal Indonesia yang sedang berada di luar yurisdiksi Indonesia. Kekosongan hukum ini disebabkan oleh karena Indonesia belum meratifikasi Konvensi Arrest of Ships 1999. Sementara itu, tidak semua Negara dapat meratifikasi Konvensi Arrest of Ships 1999 tersebut, dikarenakan terdapat suatu klausula dalam Konvensi tersebut yang dapat membahayakan kedaulatan suatu negara. Kekosongan hukum ini sudah barang tentu juga dapat berimbas pada terhambatnya bisnis pelayaran internasional.

Pada penelitian dan penulisan yang dilakukan penulis sebelumnya, telah dibahas dan ditemukan bahwa guna mengakomodir kebutuhan aturan hukum akibat tidak diratifikasinya konvensi Arrest of Ships 1999, adalah dengan mencantumkan klausula Sister Ship dalam salah satu dokumen penjaminan Hipotek kapal, dokumen yang yang tepat dalam hal ini adalah SKMH (Surat Kuasa Memasang Hipotek). Kendati demikian walaupun hal ini dipraktekkan, tetap ada hambatannya karena SKMH adalah tidak wajib.

\section{PERUMUSAN MASALAH}

Mendasarkan pada latar belakang di atas, maka permasalahan yang akan dibahas pada penelitian ini adalah solusi hambatan penerapan sister ship binding clause (klausula pengikatan sister ship) guna perlindungan hukum kreditor Hipotek lebih baik.

\section{PEMBAHASAN}

Jaminan pada hakekatnya adalah suatu hal yang disepakati dalam suatu perjanjian dan digunakan untuk memberikan suatu keadaan aman bagi suatu pihak. Tidak dapat dipungkiri bahwa jaminan sebagaimana di atas akan seringkali terjadi sebagai salah satu konsekuensi dari perikatan yang lahir dari perjanjian utang-piutang di masyarakat, oleh karenanya diperlukan pranata hukum yang memuat norma-norma mengenai jaminan ini. Pembuat undang-undang memberikan jalan keluarnya dengan Hukum Jaminan. Hukum jaminan merupakan pranata hukum yang mengatur mengenai pembebanan jaminan sebagai tindak lanjut dari perjanjian utangpiutang, yang melingkupi pengaturan baik itu jaminan perorangan juga jaminan kebendaan, dengan tujuan untuk memberikan kepastian kepada pihak kreditor akan terlunasi piutangnya, sehingga pihak debitor lebih mudah dalam mendapatkan fasilitas kredit.

Benda jaminan oleh karenanya juga tidak kalah pentingnya. Benda jaminan tidak bisa berupa benda yang ala kadarnya, karena setidaknya benda yang akan dijadikan obyek jaminan itu haruslah memenuhi apa yang tersirat dalam Pasal 1131 BW, antara lain terdapat 2 (dua) unsur, yaitu mempunyai nilai ekonomis, dan dapat dipindahtangankan (hak kepemilikannya berpindah). Mempunyai nilai ekonomis ini tidak harus bagi masyarakat pada umumnya, karena memang terdapat beberapa benda yang mempunyai nilai ekonomis bagi sebagian orang saja, dan untuk eksekusinya juga sudah barang tentu dengan mengharapkan pembeli dari peminat benda tersebut. Kemudian untuk unsur dipindahtangankan, harus dengan proses pembelian, semua lembaga jaminan melarang pihak kreditor untuk memiliki obyek jaminan.

Hukum jaminan yang ada pada saat ini di Indonesia, pengaturannya tersebar, mengingat terdapat beberapa lembaga jaminan yang diakui di Indonesia, yang kemudian diatur dalam UndangUndang tersendiri. Sebagai salah satu cara identifikasi yang paling mudah, Hukum Jaminan diatur dalam BW dan di luar BW. Diatur dalam BW ada dalam Buku II BW dan di luar Buku II BW (ada pada Buku III BW), sedangkan yang diatur di luar BW itu dihimpun dalam suatu undang-undang tersendiri. Pengaturan yang paling banyak tersebar, dan tidak ada unifikasi hingga kini, adalah pengaturan lembaga jaminan Hipotek.

Agar dapat dijadikan obyek jaminan Hipotek, maka kapal haruslah didaftarkan terlebih dahulu, redaksi Pasal 314 Wetboek van Koophandel menegaskan bahwa untuk suatu kapal dapat didaftarkan, haruslah mempunyai bobot minimal 20 
Fani Martiawan Kumara Putra, Rekonstruksi Surat Kuasa Memasang Hipotek Dengan Pencantuman Klausula Kewajiban Pengikatan Sister

$\mathrm{m}^{3}$ (dua puluh meter kubik). Batasan tentang ukuran kapal yang dapat didftarkan ini telah dirubah dengan ketentuan Pasal 158 UU Pelayaran yang menegaskan bahwa kapal yang dapat didaftarkan adalah yang berbobot sekurang-kurangnya 7GT (gross tonnage). Pasal 60 UU Pelayaran menegaskan bahwa apabila kapal telah didaftarkan dan akan dijadikan agunan, maka lembaga jaminan Hipotek yang dipergunakan, dapat dibebani Hipotek dan menjadi objek Hipotek. Berdasarkan Pasal 1 angka 12, Pasal 158, dan Pasal 60 UU Pelayaran, maka unsur-unsur yang tercantum dalam Hipotek kapal adalah:

1. Adanya hak kebendaan, yang berupa hak jaminan kebendaan;

2. Objeknya adalah kapal laut yang beratnya minimal 7 GT (gross tonnage);

3. Kapal tersebut harus didaftarkan;

4. Diberikan dengan akta otentik;

5. Menjamin tagihan utang.

Melekat juga beberapa asas pada Hipotek, antara lain Asas Publisitas (Openbaarheid), yang berarti bahwa pengikatan hipotek harus didaftarkan dalam register umum agar masyarakat khususnya pihak ketiga dapat mengetahuinya. Asas yang berikutnya adalah Asas Spesialitas, yaitu pengikatan Hipotek hanya dapat dilakukan atas benda yang ditunjuk secara khusus.

Hipotek sebagai jaminan yang melibatkan benda, mensyaratkan adanya benda khusus yang diikat sebagai jaminan dalam perjanjian utang-piutang. Pembebanan Hipotek atas kapal dapat ditujukan pada kapal laut, kapal nelayan dan kapal yang berlayar di perairan sungai dan danau, hal ini didasari oleh Pasal 6 ayat (1) PERMENHUB Pendaftaran Kapal yang menegaskan bahwa pendaftaran hak milik atas kapal dibedakan dalam 3 (tiga) kategori: (a) kapal laut; (b) kapal nelayan; dan (c) kapal yang berlayar di perairan sungai dan danau. Demikian artinya Hipotek dapat dibebankan kepada kapal laut, kapal nelayan, dan kapal yang berlayar di perairan sungai dan danau. PERMENHUB Pendaftaran Kapal menentukan bahwa kapal dapat didaftarkan di Indonesia oleh pemilik kepada Pejabat Pendaftar dan Pencatat Baliknama Kapal (Pasal 2 ayat (2)), di tempat unit kerja bidang pendaftaran dan kebangsaan kapal pada Direktorat Jenderal Perhubungan Laut atau pelabuhan tempat pendaftaran kapal sebagaimana disebut dalam
Lampiran I PERMENHUB Pendaftaran Kapal (Pasal 4 ayat (1)), dengan syarat (Pasal 5 ayat (2)):

1. Memiliki volume kotor minimal 7 GT (tujuh gross tonnage);

2. Dimiliki oleh Warga Negara Indonesia atau Badan Hukum yang didirikan berdasarkan Hukum Indonesia dan berkedudukan di Indonesia;

3. Dimiliki oleh Badan Hukum Indonesia yang merupakan usaha patungan yang mayoritas sahamnya dimiliki oleh Warganegara Indonesia. Pengikatan benda sebagai jaminan ini haruslah dengan perjanjian tersendiri, di luar perjanjian utang-piutang. Hal ini karena fungsi dari perjanjian pengikatan jaminan kebendaan itu berbeda dengan perjanjian utang-piutang, perjanjian utang-piutang fungsinya melahirkan hak dan kewajiban terkait pemberian utang dan pembayaran utang, sedangkan perjanjian jaminan fungsinya melahirkan kewajiban si debitor untuk menyerahkan benda yang akan dijaminkan untuk dapat dibebani hak jaminan kebendaan. Inilah pada dasarnya mengapa perjanjian jaminan itu dibuat terpisah dari perjanjian utangpiutang, namun masih dalam satu kesatuan. Terpisah namun masih menjadi satu kesatuan itulah yang membuat perjanjian jaminan disebut perjanjian tambahan (asesoir), dan perjanjian utang-piutang disebut sebagai perjanjian utama (pokok).

Eksistensi perjanjian jaminan Hipotek sebagai tambahan adalah mengikuti perjanjian pokok, manakala perjanjian pokok hapus, artinya utangpiutang telah selesai, maka sudah barang tentu perjanjian jaminan juga akan ikut hapus pula. Sedangkan manakala perjanjian jaminan Hipotek hapus, belum tentu perjanjian pokok juga hapus, karena bisa saja perjanjian jaminannya hapus karena objek jaminannya di eksekusi, dan masih menunggu pembayaran untuk melunasi kewajiban pada perjanjian pokok, atau bisa juga perjanjian jaminannya hapus karena objek jaminannya hilang atau musnah.

Selain kapalnya itu haruslah terdaftar terlebih dahulu, sebagai salah satu prosedural pada lembaga jaminan Hipotek yang harus dipenuhi adalah dilanjutkan dengan dilakukannya pendaftaran jaminan Hipotek. Pendaftaran adalah cara memenuhi asas publisitas yang harus dipenuhi guna syarat sah lahirnya hak jaminan kebendaan Hipotek kapal, awal 
mula pengaturannya adalah sebagaimana ditegaskan dalam Pasal 1179 BW, yaitu pembukuan segala ikatan Hipotek harus dilakukan dalam register-register umum yang disediakan untuk itu, dan apabila tidak dilakukan maka suatu Hipotek tidak akan memiliki kekuatan apapun. Publisitas Hipotek kapal pada saat ini diatur dalam Pasal 60 ayat (2) UU Pelayaran, yang menegaskan bahwa pendaftaran Hipotek kapal dilakukan oleh Pejabat Pendaftar Pencatat Baliknama Kapal (P3BK) di tempat pendaftaran kapal.

Berdasarkan Pasal 33 ayat (2) Peraturan Pemerintah No. 51 Tahun 2002 tentang Perkapalan, ditegaskan bahwa pembebanan Hipotek pada P3BK harus dengan dokumen berupa: 1. Grosse Akta pendaftaran atau baliknama kapal; 2. Perjanjian kredit.

Pengaturan lebih lanjut mengenai teknis pendaftaran terdapat dalam Pasal 29-32 PERMENHUB Pendaftaran Kapal. Sebagai mekanisme akhirnya, Akta Hipotek disimpan oleh P3BK, kemudian P3BK memberikan Grosse Akta Hipotek Kapal, Grosse Akta Pendaftaran Kapal, dan Grosse Akta Baliknama Kapal kepada penerima Hipotek (kreditor). Demikian beberapa tahapan penjaminan Hipotek kapal sebenarnya cukup singkat, yaitu: 1. Pembuatan perjanjian pokok (utangpiutang); 2. Pendaftaran Hipotek pada P3BK.

Singkatnya proses pembebanan Hipotek tersebut, memang cukup memudahkan bagi para pihak yang mengikatkan diri didalamnya, khususnya adalah pihak kreditor. Kendati demikian, tidak begitu kenyataanya manakala memperhatikan susbstansi yang ada pada dokumen penjaminan Hipotek, yang telah disediakan (dibakukan) dalam pengaturan PERMENHUB Pendaftaran kapal. Sebagaimana Akta Hipotek kapal yang ditentukan melalui Pasal 30 dan juga Contoh 10 Lampiran II PERMENHUB Pendaftaran Kapal. Klausula yang ada ini, ternilai tidak cukup memberikan perlindungan hukum yang kuat bagi pihak kreditor khususnya. Oleh karenanya, para pihak mencari jalan keluarnya dengan cara membuat SKMH terlebih dahulu.

Pada penelitian sebelumnya, penulis telah menjabarkan kegunaan dari SKMH. Pada penjaminan Hipotek ini, SKMH bukanlah merupakan suatu kewajban, kendati demikian SKMH tetap digunakan dalam penjaminan Hipotek, mengingat klausula yang ada dalam SKMH itu lebih dapat melindungi para pihak, khususnya pihak kreditor, selain itu, manakala ada janji-janji tambahan yang ingin diikat oleh debitor dan kreditor, SKMH dapat menjadi wadahnya, mengingat tidak ada form baku untuk SKMH ini, asas kebebasan berkontrak (sebagaimana Pasal 1338 BW) berlaku sepenuhnya, walau memang pada SKMH tetap harus ada klausula mengenai inti dari kegunaan SKMH tersebut, yaitu menghindari keterlambatan atau penundaan pendaftaran jaminan Hipotek karena debitor yang berhalangan waktunya. Inilah salah satu sebab pada Akta Hipotek yang formnya dibakukan itu tersedia kolom untuk dituliskan mengenai adanya SKMH atau tidak pada penjaminan tersebut.

Pendaftaran perjanjian jaminan pada hakekatnya ditujukan agar pihak ketiga mempunyai kesempatan untuk mengetahui bahwa benda-benda tertentu terikat sebagai jaminan untuk keuntungan kreditor tertentu, untuk suatu jumlah tertentu, dengan janjijanji tertentu. Artinya pendaftaran mempunyai akibat terhadap pihak ketiga di luar perjanjian utang-piutang dengan jaminan. Melalui pendaftaran perjanjian jaminan, maka pihak ketiga secara tidak langsung menjadi terikat dengan perjanjian utang-piutang dengan jaminan yang ada, dalam bentuk dianggap mengetahui dan diwajibkan untuk menghormati proses utang-piutang yang membebani benda tersebut. Sehingga manakala pihak ketiga melakukan suatu perbuatan hukum terhadap benda tersebut (contohnya membeli), maka pihak ketiga diwajibkan memikul resiko saat benda tersebut sewaktu-waktu akan dilakukan eksekusi atas dasar utang yang telah jatuh tempo. Demikian artinya pihak ketiga akan dianggap beritikad baik, manakala akan melakukan perbuatan hukum terhadap suatu benda, itu memeriksa terlebih dahulu pada buku pendaftaran atau register di tempat lembaga jaminan yang bersangkutan untuk jenis benda tersebut, guna memastikan apakah benda yang mau dilakukan perbuatan hukum terhadapnya itu tidak sedang dibebani jaminan.

Cukup banyak kendala yang muncul baik itu saat kapal yang dijadikan obyek jaminan sedang berada di dalam negeri, ataupun sedang di luar yurisdiksi Indonesia. Pada penelitian sebelumnya, penulis menemukan satu cara untuk eksekusi itu tetap dapat dilakukan saat kapal berada di luar yurisdiksi Indonesia, yaitu dengan pembaharuan pengaturan Hipotek kapal disertai beberapa substansi pengaturan adopsi, serta peningkatan P3BK, hingga keterlibatan 
Fani Martiawan Kumara Putra, Rekonstruksi Surat Kuasa Memasang Hipotek Dengan Pencantuman Klausula Kewajiban Pengikatan Sister Ship Manakala Jalur Pelayaran Dominan Lintas Batas Negarea

sister ship pada penjaminan Hipotek kapal. Tentunya disamping cara tersebut, masih harus ditemukan cara-cara lain guna semakin memberikan kepastian hukum pada pihak kreditor bahwa utangnya pasti terlunasi, dengan demikian lembaga jaminan Hipotek tetap eksis sebagai lembaga jaminan yang luwes dan dibutuhkan masyarakat dalam perkembangan jaman ini.

Perihal eksekusi oyek jaminan Hipotek yang lintas batas negara, terdapat 3 (tiga) Konvensi yang dapat dijadikan dasar hukumnya, yaitu yang pertama adalah International Convention on Maritime Liens and Mortgage 1993, kedua adalah International Convention Relating to the Arrest of Seagoing Ships 1952, ketiga adalah Arrest of Ships 1999.

Indonesia meratifikasi International Convention on Maritime Liens and Mortgage 1993, namun Belanda tidak meratifikasinya, yang diratifikasi adalah International Convention Relating to the Arrest of Seagoing Ships 1952 (Brussels, 10 May 1952) yang mana konvensi ini tidak diratifikasi Indonesia. Artinya saat kapal Indonesia yang di Hipotekkan Indonesia berlayar dan bersandar di Belanda, Belanda bebas untuk tidak mengakui Hipotek yang melekat pada kapal tersebut. Namun pada praktiknya Belanda menghormati Hipotek yang melekat pada kapal asing yang bukan bagian dari Eropa (European Union) atas dasar kebiasaan dan menghormati hubungan atau kerjasama internasional yang ada dengan negara bendera kapal tersebut.

Konvensi Arrest of Ships 1952 ini hanya berlaku manakala kapal yang ditahan oleh Dutch Arresting Party adalah kapal yang mengibarkan bendera negara yang juga menjadi peserta Konvensi tersebut (termasuk kapal Belanda sendiri), dan ditahan atas adanya Maritime Claim, karena Konvensi ini pada intinya adalah "arresting ship by judicial process to secure a maritime claim". Sebaliknya apabila penahanan yang dilakukan di Netherland itu terhadap kapal yang mengibarkan bendera bukan dari Negara peserta Konvensi Arrest of Ships 1952, atau ditahan bukan karena adanya Maritime Claim, maka hukum Negara Belanda yang diterapkan.

Hal di atas ini sebagaimana Pasal 8 Konvensi Arrest of Ships 1952 yang menegaskan "The provisions of this Convention shall apply to any vessel flying the flag of a Contracting State in the jurisdiction of any Contracting State". Jadi manakala kapal Negara Belanda ditahan oleh pihak dari Negara Belanda sendiri atas dasar adanya Maritime Claim, maka Konvensi Arrest of Ships 1952 diberlakukan. Manakala kapal Negara Belanda ditahan oleh pihak Negara Belanda sendiri bukan karena adanya Maritime Claim, maka yang diberlakukan adalah hukum intern Negara Belanda sendiri. Begitu juga dengan kapal negara Indonesia (yang tidak meratifikasi Konvensi ini) ditahan oleh pihak Negara Belanda baik karena ada atau tidak ada Maritime Claim, yang diberlakukan adalah hukum intern negara Belanda.

Terdapat 17 (tujuh belas) jenis maritime claim dalam Konvensi Arrest of Ships 1952 yang dapat menyebabkan kapal ditahan di Belanda. Terdapat juga yang bukan merupakan maritime claim. Sedangkan beberapa jenis klaim yang bukan tergolong maritime claim dalam Konvensi Arrest of Ships 1952 adalah:

1. Outstanding insurance premiums, including calls of P\&I clubs;

2. Claims in respect of a sale and purchase agreement regarding a vessel;

3. Oil pollution claims;

4. Broker's commission and probably also claims of stevedores.

Pada Pasal 3 Konvensi Arrest of Ships 1952, negara peserta diperkenankan untuk menahan "sister vessel" yaitu kapal yang mempunyai karakter identik dengan kapal sedang dicari dan akan ditahan, namun tentunya kapal tersebut harus terdaftar juga atas nama pemilik yang sama dengan kapal yang dicari dan akan ditahan itu.

Manakala Dutch Arresting Party menahan kapal yang berasal dari negara yang bukan peserta dari konvensi Arrest of Ships 1952, atau bukan karena Maritime Claim, itu tetap diperbolehkan melalui pengaturan dalam Pasal 267 Buku 3 NBW.

Kreditor pemegang jaminan Hipotek kapal di Belanda dapat mengambil alih (menyita) kapal yang diHipotekkan, manakala debitor sudah tidak mampu melaksanakan kewajibannya pada kreditor, dan telah disetujui oleh Pengadilan. Jadi dalam ketentuan di atas ini adalah diperbolehkannya Sita Eksekusi. Dapat juga diperjanjikan dalam akta Notariil Hipotek kapal, bahwa kreditor berhak menguasai benda-benda

1 Gianluca Kreuze, et.al.. (2014). Ship Finance in Netherlands. First Edition. Rotterdam: Loyen \& Loeff N.V., p. 84. 
tertentu pada kapal tersebut (yang juga ikut terbebani Hipotek kapal yang dimilikinya), untuk mendukung pelaksanaan penyitaan tersebut. Baik sita eksekusi, sita jaminan dan prosedur-prosedur lain terkait dengan penyitaan dan eksekusi, diatur lebih lanjut dalam Wetboek van Burgerlijke Rechtsvordering atau Dutch Code of Civil Procedure, yang merupakan Kitab Undang-Undang Hukum Acara Belanda yang baru.

Saat kapal berada dalam penyitaan, pemilik kapal tetap menjadi pihak yang bertanggungjawab atas perawatan kapal tersebut. Pada praktiknya manakala kapal yang disita tersebut dalam rangka pelunasan penjaminan Hipotek kapal, secara otomatis pihak kreditor akan memastikan dengan segala upayanya agar kapal tersebut tetap aman, terawat, sehingga harga jual tidak menurun. Biaya-biaya perawatan kapal ini dapat diklaimkan pada saat eksekusi, dan mempunyai peringkat di bawah Hipotek kapal namun diutamakan daripada klaim lainnya. Berbeda halnya dengan pengaturan yang ada di Indonesia dengan adanya asas Rijdende Beslag yang tertuang dalam Pasal 577 dan 578 Rv, pada pengaturan hukum Belanda yang baru, asas ini telah tidak diberlakukan baik untuk penyitaan yang menggunakan Konvensi Arrest of Ships 1952 atau pun yang menggunakan hukum intern Belanda. Mengingat Belanda telah menyesuaikan dengan pengaturan Pasal 3 ayat (1) Konvensi Arrest of Ships 1952, yang redaksinya adalah kapal dengan maritime claim dapat ditahan, atau kapal yang serupa (sister ship) juga dapat ditahan asalkan sama pemiliknya, bahkan saat kapal tersebut siap berlayar. Tetapi kapal yang serupa (sister ship) tidak dapat dilakukan penahanan manakala tidak berkaitan dengan sengketa kepemilikan, sengketa antara pemilik, atau sengketa Hipotek.

Ketentuan di atas kemudian menjadi dasar ketentuan dalam Pasal 563 ayat (1) dan (2) jo. 564 ayat (3) Wetboek van Burgerlijke Rechtsvordering Belanda. Hal ini kemudian menjadi embrio pemikiran pemanfaatan sister ship sebagai salah satu cara mewujudkan kepastian hukum pihak kreditor dalam hal eksekusi obyek jaminan Hipotek saat obyeknya sedang berada di luar Yurisdiksi.

Indonesia tidak meratifikasi baik itu Arrest of Ships Convention 1952 dan Arrest of Ships Convention 1999, namun Indonesia meratifikasi International Convention On Maritime Liens and
Mortgage 1993, pengaturan pada konvensi ini sudah dapat menjadi titik anjak bagi pemerintah Indonesia untuk mengatur pengikatan sister ship sebagai suatu jaminan tambahan atau cadangan, mengingat pengaturan sister ship sebagaimana dibahas di atas itu arise from maritime claim, dan Hipotek termasuk didalamnya.

Manakala pembuat undang-undang belum mampu melakukan pembaharuan hukum bagi lembaga jaminan Hipotek kapal dengan semua substansi yang telah ditemukan penulis dalam penelitiannya, maka dalam hal implementasi sister ship, dapat dilakukan dengan cara diperjanjikan, yang mana tentunya diperjanjikan dalam SKMH, sebagaimana sebelumnya telah dibahas, SKMH berlaku asas kebebasan berkontrak dalam Pasal 1338 BW.

Klausula yang diharapkan adalah debitor setidaknya memiliki kapal kembaran, yang tentunya dengan nilai yang sama dengan kapal yang akan dijaminkan. Kapal ini kemudian diikat dengan klausula dalam SKMH, dan ditentukan boleh untuk digunakan namun tidak boleh dijadikan agunan, juga tidak boleh digunakan untuk berlayar melintasi yurisdiksi Indonesia selama proses utang-piutang dan penjaminan Hipotek berlangsung.

Dimungkinkan pula yang dijadikan kembaran itu adalah kapal yang masih dalam tahapan pembangunan, sehingga nanti saat pembangunan kapal selesai itu bertepatan dengan waktu piutang selesai.

Sifatnya ini hanyalah jaminan tambahan, untuk dapat di eksekusi manakala kapal utama yang dibebani jaminan Hipotek itu sedang berada di luar yurisdiksi dan kesulitan untuk dilakukan eksekusi.

Pengawasan terhadap sister ship secara berkala, asas spesialitas, asas publisitas, keilmuan, kerjasama dan profesionalisme P3BK berperan penting dalam hal ini. Kendati hal ini adalah hal yang baik, akan tetapi untuk pelaksanaan eksekusi sister ship ini sudah barang tentu tidak bisa menggunakan titel eksekutorial ataupun parate executie, jadi penjualannya dilakukan secara pribadi atau dibawah tangan. Hal ini mengingat grosse akta Hipotek dikeluarkan bukan untuk sister ship (kapal kembarannya), melainkan untuk kapal utama yang dibebani jaminan Hipotek. 
Fani Martiawan Kumara Putra, Rekonstruksi Surat Kuasa Memasang Hipotek Dengan Pencantuman Klausula Kewajiban Pengikatan Sister Ship Manakala Jalur Pelayaran Dominan Lintas Batas Negarea

Penerapan sister ship sebagaimana di atas, tidak selalu berjalan dengan baik, mengingat dasar pengikatannya adalah perjanjian, dan syarat utama dari perjanjian adalah sepakat. Pengikatan sister ship tidak akan terjadi walaupun debitor memiliki sister ship dan kreditor membutuhkannya untuk kepastian pelunasan utangnya, namun debitor tidak mau untuk sepakat mengenai klausula pemanfaatan sister ship ini. Jalan keluar dari pemasalahan ini adalah perlu adanya campur tangan pemerintah melalui pembuat undang-undang.

Walau tidak berupa undang-undang, bisa berupa Peraturan Menteri Perhubungan atau Peraturan Pemerintah, yang mana mewajibkan untuk menggunakan klausula sister ship manakala kapal debitor yang akan dijaminkan itu berlayar melintasi yurisdiksi Indonesia. Karena aturan kewajibannya ada dalam Undang-Undang atau Peraturan Pemerintah atau Peraturan Menteri Perhubungan, maka klausula tersebut tidak ditempatkan dalam SKMH, melainkan ditempatkan pada Akta Hipotek, mengingat SKMH sifatnya adalah opsional sebagaimana dijabarkan di atas. Demikian manakala debitor dan/atau kreditor sepakat untuk mengesampingkan pemanfaatan sister ship ini, maka artinya pihak tersebut harus memikul resiko atas kerugian yang diderita karena tidak mengikuti amanah dan fasilitas yang diberikan oleh pemerintah.

\section{PENUTUP}

\section{Kesimpulan}

Permasalahan eksekusi kapal yang dijadikan objek jaminan Hipotek di Indonesia manakala pelayarannya melintasi yurisdiksi Indonesia, adalah permasalahan salah satu permasalahan yang pemerintah Indonesia tidak kunjung memberikan jalan keluarnya. Berbagai temuan dari penelitian penulis dapat diterapkan dengan cara mengadakan pembaharuan hukum lembaga jaminan Hipotek Kapal. Salah satu fasilitas temuan yang tidak memerlukan pembaharuan hukum untuk dapat diterapkan adalah penggunaan sister ship sebagai jaminan tambahan, hal ini karena sifatnya cukup diikat dengan perjanjian. Klausula dalam perjanjian tersebut tentunya juga harus komprehensif, dan yang terpenting adalah sister ship itu tidak boleh diikat sebagai agunan pada utang debitor kepada pihak lain. Kendati demikian karena hanya berdasar pada perjanjian, artinya dibutuhkan kesepakatan oleh para pihak sebagai syarat utamanya, dapat terjadi debitor tidak sepakat walau sejatinya kreditor sangat membutuhkannya untuk perlindungan dan kepastian pelunasan utangnya. Oleh karena itu perlu adanya campur tangan pemerintah untuk memfasilitasi, baik itu berupa Undang-Undang, Peraturan Pemerintah, ataupun Peraturan Menteri Perhubungan. Isinya adalah kewajiban untuk menggunakan klausula sister ship manakala kapal debitor yang akan dijaminkan itu berlayar melintasi yurisdiksi Indonesia. Demikian karena dari pemerintah, maka klausula tersbut tempatnya bukan lagi dalam SKMH, namun dalam Akta Hipotek, karena manakala klausula itu wajib, maka tidak sepatutnya ditempatkan pada SKMH yang sifatnya tidak wajib. Hal ini benar-benar harus diperhatikan oleh Pemerintah. Mengingat hal-hal ini tidak terjangkau dalam pembaharuan Hukum yang dilakukan oleh Pemerintah. Seperti contohnya adalah PERMENHUB Pendaftaran Kapal, sebelum diterbitkan Tahun 2017, telah ada PERMENHUB Pendaftaran Kapal di Tahun 2012, dan sebagaimana telah dijabarkan penulis dalam penelitian sebelumnya, perubahan yang ada pada PERMENHUB Pendaftaran Kapal Tahun 2012 dan 2017 itu mengenai Hipoteknya sangat minimal, bahkan tidak ada perubahan yang berarti, dalam permasalahan yang ada seperti dokumen hukum dan eksekusi obyek jaminan Hipotek kapal.

\section{Rekomendasi}

Pemerintah diharapkan lebih sensitif dalam memperhatikan lembaga jaminan di Indonesia, khususnya mengenai Hipotek dengan beberapa permasalahannya. Diperlukan pembaharuan hukum lembaga jaminan Hipotek, untuk temuantemuan mengenai penyelesaian utang-piutang dengan jaminan Hipotek kapal, baik itu dari bagian dokumennya, pihak pencatatnya, dan eksekusinya.

\section{DAFTAR PUSTAKA}

\section{Peraturan Perundang-undangan:}

Undang-Undang Nomor 17 Tahun 2008 tentang Pelayaran.

International Convention Relating to the Arrest of Seagoing Ships 1952.

Nieuw Burgerlijk Wetboek.

Wetboek van Burgerlijke Rechtsvordering. 
International Convention on Maritime Liens and Mortgage 1993.

Arrest of Ships Convention 1999.

Peraturan Pemerintah Nomor 51 Tahun 2002 tentang Perkapalan.

Peraturan Menteri Perhubungan Nomor 39 Tahun 2017 tentang Pendaftaran dan Kebangsaan Kapal.

\section{Buku:}

Burgerlijk Wetboek.

Sri Soedewi. (2007). Hukum Jaminan di Indonesia, Pokok-Pokok Hukum Jaminan dan Perorangan. Yogyakarta: Liberty.

Kartini Muljadi dan Gunawan Widjaja. (2005). Hak Istimewa, Gadai dan Hipotek. Jakarta: Kencana.

Gianluca Kreuze, et.al. (2014). Ship Finance in Netherlands. First Edition. Rotterdam: Loyen \& Loeff N.V.
Arnold J. van Steenderen. (2015). Getting the Deal Through Shipping 2015 Netherlands. London: Law Business Research.

Moch. Isnaeni. (2016). Pengantar Hukum Jaminan Kebendaan. Surabaya: Revka Petra Media.

\section{Jurnal:}

Muhammad Arfin Muhammad Salim. "Authenticating the Tourist Destination on the Official Tourism Website of Indonesia: A Multimodal Perspective". Astra Salvensis. VI 2018, Supplement no. 1 (2018).

Soeling Pantius D. "Enhancing Regional Competitiveness Through Village Owned Enterprise in East Priangan Indonesia". Astra Salvensis. VI 2018, Supplement no. 1 (2018). 